\title{
Jung, the Pentateuch and ethics
}

Eben Scheffler

(University of South Africa)

... the opposite to love ... is power.

- C G Jung

ABSTRACT

\section{Jung, the Pentateuch and ethics}

This article reflects on the contribution that can be made to the interpretation of the Bible by employing the analytical psychology of Carl Jung. After some relevant biographical considerations on Jung, his view of religion and the Bible is briefly considered, followed by a look into Genesis 1-3 in terms of his distinction of archetypes. It is suggested in the conclusion that Jungian psychological Biblical criticism can lead to a changed, but fresh view on the 'authority' or influence of the Bible in the lives of (post)modern human beings and their (ethical) behaviour.

\section{INTRODUCTION.}

Despite some vital changes in recent years (cf Kille 2001, with its extensive bibliography) the possibility of psychological exegesis is questioned by Biblical exegetes (cf Smit 1988:441-450) and has received less attention in Biblical studies than for instance, psychology's sister subject, sociology (cf Scheffler 1988:355) ${ }^{1}$.

There are various reasons for this lack of interest in psychological exegesis, one of which may be that exegetes with a sincere theological commitment may fear that if something is 'psychologically' explained, it cannot be believed anymore. This represents an argument in terms of analogy: If psychology, for instance, can explain a neurosis you might suffer in terms of an earlier (usually traumatic) event in your life, you obtain insight into that event which causes it to recede. Applied to theology: if your faith or a religious phenomenon is psychologically explained, its reason for existence also falls away. This analogical reasoning is of course illogical.

1 For a brief history of the psychological approach, see Scheffler (1994:150-152) and Kille (2001:29-37). 
Not only distrust, but profound theological presuppositions caused the enmity between psychology and theology to be maintained. Psychology was (cf Harsch 1972:49-51) regarded by dialectical theology as human thinking, 'Denken von Menschen her'; it represents a human attempt to save man and therefore should be demolished by the Word of God. Psychology should not be allowed to reduce the 'theologische Anspruch' of the Biblical text (Strecker \& Schnelle 1983:149). Dialectical theology of course had a blind spot for the fact that all thinking represents human thinking, however loaded its religious content may be. Few theologians today will not concede to this.

Then there is of course the atheism of Sigmund Freud that can be mentioned as a third factor contributing to the aversion which theology felt towards anything 'psychological'. At the beginning of the 20th century, Freud dominated the psychological scene and theologians took what he said as representative of the 'psychological' perspective. And as far as religion is concerned, Freud was quite outspoken and published widely. In Die Zukunft einer Illusion (1979) he diagnosed religion as an illusion, a projection of the human soul (à la Feuerbach). For any person with pro-Pentateuch sentiments, his book Der Mann Moses und die monotheistische Religion (1975), can only be regarded as an attack on the Jewish-Christian faith.

There is a certain degree of tragedy in the fact that Freud so harshly made his statements that he was generally so well heard by theologians that they refrained from going into dialogue with him (the work of Scharfenberg [1971] and Uleyn [1985] being important exceptions). Ironically, during the same time that Freud published his work on religion, the famous American psychologist, philosopher and theologian, William James, also wrote extensively on religion and psychology (e g 1902). James could have been a partner to theology, since he endeavoured to advocate a (although reinterpreted) positive religious view. In The varieties of religious experience, James (1902:495-528) affirms that the world is richer in realities that conventional science is willing to admit to. According to him religious experience suggests that there is a 'higher part of the universe' which can be called 'God' and which produces 'real effects'. Although we lack the knowledge to define this 'higher part', James holds that it can be conceived as an infinite power or powers which, like men, work(s) toward the good and help(s) to 
achieve it. Apparently, Freud's denial of God's existence closed the ears of theologians for James's views. Moreover James' views were probably also regarded as unconventional and therefore heretical ${ }^{2}$.

As suggested above, some changes have occurred in recent years. Various Biblical exegetes and systematic theologians have shown a positive interest in psychological exegesis, for example Spiegel (1972), Theissen (1983), Kille (2001), Rollins (1983), Drewermann (1984; 1985), Bryant (1983), Watt (1995), Newheart (1994), Brown (1995), Miller (1995), Leiner (1993), Edinger (1986; 1987), to mention but a few ${ }^{3}$. Many of these authors have employed psychological exegesis to come to a more profound understanding of the Bible and others to 'save' or affirm the value or theological claim of the text. In this process the analytical psychology of the Swiss psychiatrist, Carl Jung, plays a prominent role. In the context of the Pro-Pent seminar ${ }^{4}$ this article is meant as a brief introduction (with reference to Gn 1-3) to the challenges posed by Jung's psychology for the study of the Pentateuch and its ethical implications (in an African context).

\section{REMARKS ON JUNG'S BIOGRAPHY AND VIEW OF RELIGION}

The fact that Jung's work functions prominently among Biblical scholars interested in psychological biblical criticism, is partly due to the extensive interest which Jung himself showed in the Bible and

2 Although James was the son of a cleric (like Jung) he did not limit his personal view on God to that of the exclusive, infinite and omnipotent God of traditional theism who guarantees the successful outcome of the universe (cf Earle 1967).

3 When I published my first article on psychological exegesis (cf Scheffler 1988; cf also 1990;1991;1992;1994), I remarked in a footnote that I could not find (except for Steyn's articles [1984; 1985] that employed psychological insights) any literature on psychological exegesis in South Africa. Since then the situation has changed (cf eg Gous 1992; Van Heerden 2003). Various students have also embarked on writing dissertations employing psychological criticism (eg A H Dierks on depression in the Psalter and $\mathrm{P}$ van der Zwan on the religiosity of Song of Songs).

4 The Pro-Pent Seminar is a co-project on studying the Pentateuch between the Universities of Pretoria and Munich, Germany. My thanks and appreciation for the endeavours of Proff Jurie le Roux and Eckhardt Otto in this regard. 
also to Jung's Christian and clerical background and his perceived pronounced faith in God, as manifested in the inscription above the entrance to his home in Küsnacht, Vocatus atque non vocatus, deus aderit (called or uncalled, will be present). However, one should take note that Jung's views do not imply a simple corroboration of classical Christianity in which fundamentalists can thrive. In his autobiography, Memories, Dreams, Reflections, Jung relates how he early in life came into conflict with his inherited protestant tradition and how this conflict, enhanced by the fact that his father was a minister, caused him so much pain that he refrained from attending church (1963:24-30). Despite this (or may be as a result of this!) he became critical towards his own inherited religion, but remained interested and indeed fascinated by religion itself, always stating that he does not believe there is a God, but knows it (cf McGuire \& Hull 1980:383). To a clergyman Jung wrote in 1952 (quoted in Jung 1963:13): 'I find that all my thoughts circle around God like the planets around the sun, and are as irresistibly attracted by Him'. However he also remarked ([1938] 1969:58-59): 'It would be a regrettable mistake if anybody should take my observations as a kind of proof of the existence of God. They prove only the existence of an archetypal God-image, which to my mind is the most we can assert about God psychologically'. In 1960, towards the end of his life, Jung explained the inscription above his doorways. The subtle connotations should be noted:

I have put the inscription there to remind my patients and myself: Timor dei initium sapientiae (the fear of God is the beginning of wisdom). Here another not less important road begins, not the approach to "Christianity", but to God himself, and this seems to be the ultimate question.

These remarks of Jung are important since they signify (although not necessarily an un-Christian), definitely an independent perspective on Christianity and religious matters. It also manifests itself in his use of the Bible, which represents a challenge to traditional Biblical scholars.

5 In a letter to E Rolfe, after having read the latter's book The intelligent agnostic's introduction to Christianity (1959), published in Adler (1976:610-611). 
Although unorthodox, religion was of paramount importance to Jung. In fact, it was so important that it lead to his break with Sigmund Freud, that other psychological giant of the first half of the 20th century. After close interaction and friendship with Freud which started in 1907, Jung broke with Freud in 1913. The common perception is that this occurred due to Freud's (over)emphasis on sexuality, whereas Jung mentions in his autobiography that Freud's view on religion as mere 'occultism', which therefore should be opposed at all costs, was the real reason (1963:173). Whether Jung here reveals a blind spot (in his own terms suppressing the real reason into his subconscious) is an open question. According to Rychalk the separation was (also) precipitated because of Freud's perspective that he was the senior partner in their relationship and had designated Jung as his crown prince (1973:134). Be this as it may, the contents of their psychologies show that religion constituted indeed the main disagreement between Jung and Freud, especially in terms of Jung's positive appropriation thereof. As far as sexuality is concerned, Jung interpreted the concept of the libido (for Freud the instinctual sexual drive) in a wider sense as the 'life energy' at the basis of all human activity ${ }^{6}$.

\section{JUNG'S VIEW ON THE BIBLE}

Jung made the following astonishing remark, which can be misunderstood by pious Bible- readers: 'We must read the Bible or we shall not understand psychology. Our psychology, our whole lives, our language and imagery are built upon the Bible' (Jung

6 It is ironical that the 'sex-obsessed' Freud, who held that focus on the sexual question should serve 'as a bulwark against occultism' (Jung 1963:173), remained faithful to his wife his whole life, whereas even the most devoted Jungian won't make this claim with regard to Jung. Jung is known to have had a special relationship with Toni Wolff (one of his coworkers). On the question whether this relationship was of a sexual nature, one of his biographers remarks (Brome 1978:131): 'Conflicting evidence clouds the inevitable question - did he sleep with her? - but one school accepted it as a fait accompli'. It is also interesting to note that Jung called for critical reflection on what 'adultery' (an important pentateuchal concept!) constitutes ([1927] 1970:129). In the context of a rather conservative South African theological circle, I wish to state categorically that I deplore employing any aspect of Jung's personal life per se as a means to discredit his academic views. See my forthcoming article on Jung, sex and the Bible. 
1975:156). This can of course only be valid for a western psychologist, and may even be objected against by those westerners who regard themselves as secular or irreligious. On the other hand, it should be kept in mind that the development of psychology as a scientific subject is a western enterprise and that in the very establishment of this subject Freud and Jung played a prominent role. The debate on religion in psychology (which in Freud and Jung found opposing voices), is therefore a central factor in the development of psychology as a scientific subject ${ }^{7}$.

Although Jung had read extensively in theology, literature and the background of the ancient Near Eastern, Greek and Roman cultures, he did not engage in formally commenting on Biblical passages. He rather went into dialogue with the 'Aussagegehalt' (= statement content) of the Biblical text. His book on Job $(1952 ; 1965)$ was therefore not an explanation, exegesis or commentary on the book of Job, but as the title indicates an Antwort auf Hiob. His writings are replete with direct and indirect references to the Biblical text, allusions to Biblical personages, places, symbols, phrases and concepts (Kille 2001:81). The index of his Collected Works (20 volumes), devotes ten pages (double column) to Biblical textual references (cf Forryan \& Glover 1979:112-121) and many more to personages and concepts (e g six pages to 'Christ' and eight to 'God'; cf Forryan \& Glover 1979:151-156, 299-306).

To appreciate Jung's view on the Bible, one should take note of his early childhood experiences in this regard. Being haunted as a young child by the theodicy problem, most of the sermons on the Bible (including those of his own father) did not satisfy him. Not being able to reconcile the existence of suffering and evil with the notion of God's love, he had problems with most of the Biblical books he read, of which those of the Pentateuch were no exception. He remarked that unfortunately he encountered the books of Job (which addressed his religious problems) too late in his life. Precisely this book that addressed the theodicy problem and the ultimate meaning of life was avoided by the church and traditional

7 So-called 'atheistic' psychologists in a western context have to account for their secular viewpoints in terms of the Judaeo-Christian heritage and the Bible. Of this Freud's classic work is but an example (cf $1975 ; 1979 ; 1980)$. For an overview on perspectives, see Van den Berg (1958). 
Christianity of his day. The decalogue and the laws of Moses seemed to provide more security for Christians and the church than the existential confrontations of Job $(1963: 59,64)$.

Although Jung often employs the concept 'Word of God', he definitely did not regard the Bible as literally the 'Word of God' or as having the authority usually ascribed to it by traditional Christianity. On the other hand, he was not disrespectful towards the Bible. On the contrary, for Jung (1965:xv) the contents one encounters in the Bible are utterances of the human soul ${ }^{8}$. These utterances '... point to realities that transcend human consciousness. These entia are archetypes of the collective unconsciousness, and they precipitate complexes of ideas in the form of mythological motifs' (Jung 1965:xv-xvi).

Although Jung criticised the historical-critical method as employed by Biblical scholars of his day ([1938] 1969:21-22), to my mind his approach need not imply an outright discarding of historical criticism, but a going beyond it and even an enriching of the method. It definitely takes exception to an absolutising of historical criticism which seems to confide in its own results and scorns at looking at the text from other angles - a sin not always avoided by its practitioners. According to Drewermann (1984:16) Jung's analytical psychology teaches every expositor of the Biblical text

dass man nicht länger das Pferd am Schwanz aufzäumen kann, indem man

die Worte für wichtiger nimmt als die Bilder, die Handlungen für wichtiger als die Gefühle und

8 The term 'soul' may be misleading, in danger of being interpreted as a loose entity separate from the human body. 'Mind' may be a better word, but probably emphasises the intellectual dimension too much. Perhaps psyche should be used, referring to the reality of the living human subject. According to Jung ([1926] 1969) '... the psyche consists essentially of images. It is a series of images in the truest sense, not an accidental juxtaposition or sequence, but a structure that is throughout full of meaning and purpose; it is a "picturing" of vital activities. And just as the material of the body that is ready for life has need of the psyche in order to be capable of life, so the psyche presupposes the living body in order that its images may live'. 
die literarische Form der Überlieferung für wichtiger als die Erlebnisse

und Erfahrungen, aus denen die einzelnen Formen erwachsen".

This powerful statement of Drewermann is directed against the 'Logozentrik der Exegese' and part of his attack on historical criticism, which is much fiercer than that of Jung himself ${ }^{10}$. It nevertheless expresses vividly what Jungian Biblical interpretation aims at: understanding of the images, feelings and experiences that not only lie beneath the text, but in fact caused it.

Applied to the study of the Pentateuch, to my mind we need not judge the historical-critical study of the past 300 years as being of no avail, but are challenged to ask which aspects, motifs, psychological dimensions or needs of humanity - which archetypes - caused the authors to create such a text as the Pentateuch. This task does not diminish the need for historical study, but enhances it, since the needs that caused the human utterances contained in the Pentateuch, derive from ancient humans situated in a specific context relating to time and space (cf Scheffler 2000:11-17).

\section{THE MEANING OF THE ARCHETYPES FOR BIBLICAL INTERPRETATION}

The study of archetypes is not the only avenue to study the Bible from a Jungian perspective (cf e.g. the studies on individuation by Edinger 1986 and Kille 1995), but the most popular. But what are these archetypes or images? They are the predispositions or psychic realities of the collective unconscious, thought patterns which in new situations are filled by context-related contents.

The archetypes spring from the collective unconscious which represents the inherited and deepest level of the unconscious which

9 Because of the importance of this statement I provide the following translation: 'One can no longer bridle the horse by its tail by regarding the words more important than the images, the actions more important than the feelings, and the literary form of the tradition more important than the experiences from which the individual forms develop' (my italicisation).

10 For a more in depth look at the role of Jung's psychology in Drewermann's psychological interpretation of the Bible, see my forthcoming article Jungian psychology in the 'tiefenpsychologische Exegese' of Eugene Drewermann. 
an individual shares with humanity at large. According to Maddi (1976:60-61) it contains the 'accumulated experience of the human species: ... the fears, joys, triumphs, tradegies, beliefs, problem solutions...' Said Jung ([1948] 1969:133-134)

... [W]e also find in the unconscious qualities that are not individually acquired but are inherited, e.g. instincts as impulses to carry out actions from necessity, without conscious motivation. In this 'deeper' stratum we also find the a priori, inborn forms of "intuitions', namely the archetypes [also called by Jung 'primordial images', Urbilder - EHS] of perception and apprehension, which are the necessary a priori determinants of all psychic processes. Just as his instincts compel man to a specifically human mode of existence, so the archetypes force his ways of perception and apprehension into specifically human patterns. The instincts and the archetypes together form the "collective unconscious". I call it "collective" because, unlike the personal unconscious, it is not made up of individual and more or less unique contents but of those which are universal and of regular occurrence.

By studying the expressions of the collective unconscious (dreams, myths, texts, symbols) knowledge about the archetypes can be obtained. The most basic or well-known archetypes (cf Rychlak 173:146) are:

(1) the persona (an individuals's social mask or public personality, cf Jung [1950] 1968:122-123; Jacobi 1968:26-30; 1978:350)

(2) the shadow (the dark 'negative' side of personality, usually repressed, cf Jung [1939] 1968:284; [1959] 1968:266-267; Jacobi 1968:109-114; Von Franz 1978:171-174; or what is regarded as 'evil' by society)

(3) the anima (the female element in the male unconscious) and the animus (the male element in the female unconscious, cf Jacobi 1968:114-124; Jung [1925] 1977:198; [1946] 1966:303-304; 1978:16)

(4) the hero (the motif of the ever-appearing rescuer, cf Jung 1978:61) 
(5) the Self (the organising center and totality of the whole psyche, cf Jung [1916] 1966:238-240; 1963:417; Jacobi 1968:126-132; Von Franz 1978:161-162).

Jung distinguished these basic archetypes (cf 1963:410-420), but it should be noted that the possibilities are endless. Being expressions of the deepest, most basic and widest experience of humanity, many archetypes, if not all, have a religious connotation. The persona in some (but not all) instances can be related to hypocrisy, the shadow to evil, the anima and animus to the divine couple, the hero to figures like Moses, David and Jesus and the Self to God, Adam before the fall, Christ or the new, 'saved' human being. By investigating the symbols and myths which religious texts offer in terms of Jung's theory on archetypes, not only the symbols and myths, but the underlying contents that sustain and generate them become comprehensible. The following archetypes are specifically religious and most relevant for psychological exegesis:

(1) original man, referring to the primordial beginning of humanity (Adam)

(2) the divine child, referring to relicts of instinctive caring, (cf the infancy narratives in the Gospels; Theissen 1983:23)

(3) God the Father, referring to relicts of a childlike begging attitude, a feeling of trust and emotional safety (cf Is 64;8; the Lord's prayer)

(4) sexual union (Eph 5:31-32), referring to mystic religious union (cf Theissen 1983:23-24)

(5) the great mother, referring to the wish for ultimate welfare through material riches (Jung 1978; Harsch 1972:55)

(6) ruler of the world, referring to the need for a ruler (e $\mathrm{g}$, Messiah, triumphant God, cf 1 Cor 15:25; Col 2:15) who will ultimately rule the world in peace (Harsch 1972:57-58), feeded by rudimentary tendencies towards impressive behaviour (Theissen 1983:23)

(7) the great priest, referring to the religious need to be like God (cf Harsch 1972:56)

(8) the wise old man, referring to the human search for wisdom or 'correct' or appropriate behaviour (cf Proverbs, Ecclesiastes) 
(9) wotan, referring to daemonic power (e.g. Satan, cf Rychlak 1973:146)

(10) paradise, referring to the golden age that once existed and will exist again (Jung 1978:77)

(11) ultimate punishment (e g hell, hiding in Lk 12 ), referring to the need for final justice.

The archetypes are not finally fixed and can be discovered on a continuous basis. According to Jung ([1954] 1968:30): ' $\ldots$ it is not sufficient just to know about these concepts and to reflect on them. Nor can we ever experience their content by feeling our way into them or by appropriating other people's feelings. It is no use to learn a list of archetypes by heart. Archetypes are complexes of experience that come upon us like fate, and their effects are felt in our most personal life'. Applied to the exegetical process: Besides for looking for known archetypes in the text, the reader should also be open to be confronted by hitherto unknown ones.

\section{GENESIS 1-3 FROM A JUNGIAN PERSPECTIVE}

The story of humanity's fall (Gn 3) prededed a perfect creation (Gn 1-2) contains the basic elements of a myth which endeavours to account for the need for an ethos which will precipitate the necessary measures or laws which regulate an ethical behaviour in a society which as such is experienced as full of danger and a threat to human well-being. It tries to explain why unethical behaviour (= 'evil') exists in the first place, with a view to counter it.

The following reflections into Gn 1-3 take Jung's own remarks dispersed over various works (cf also Kille 2001:81-107) as a point of departure. To my mind the outcome of these reflections has the advantage that religion is not merely understood as a system which produces laws and prescriptions that will enforce ethical behaviour, but as a human attitude which searches for the factors which underlie a well-functioning individual as well as society at large. The texts of Genesis 1-3 are full of mythological motifs on which Jung commented and which are thus relevant for the search for an ethic which takes the Pentateuch ('the law of Moses'!) seriously.

\subsection{Adam before the fall}

According to Jung Adam, before Eve's creation (the expression of the archetype of the original man), represents the human psyche as a whole. At that stage Adam is androgynous, male and female. In him 
the anima and animus are united. Before the fall the opposites of light and dark (the day and night of Gn 1:3-5), good and evil, the godly and the earthly, the physical and the spiritual are in harmony or equilibrium. Adam as the image of God is the symbol of the Self. Eve emanates from Adam as the embodiment of his anima or female side. Eve seeks life and procreation, and therefore convinces Adam of the goodness of the forbidden apple (the tree of life).

\subsection{The garden of Eden (paradise)}

The garden of Eden as paradise (Jung [1954] 1968:35) or place or period (golden age) of perfection is recognised by Jung as a mandala. According to Jung (1963:415) this term from the Sanskrit language

... means a circle, more especially a magic circle, and this form of symbol is not only to be found all through the East, but also among us; mandalas are amply represented in the Middle Ages. The specifically Christian ones come from the earlier Middle Ages. Most of them show Christ in the centre, with the four evangelists, or their symbols, at the cardinal points.... For the most part, the mandala form is that of a flower, cross or wheel, with a distinct tendency towards four as the basis of the structure.

Mandalas have the function of creating order in a situation of chaos. According to Jung ([1958] 1970)

Mandalas ... usually appear in situations of psychic confusion and disorientation. The archetype thereby constellated represents a pattern of order which, like a psychological 'view-finder' marked with a cross or circle divided into four, is superimposed on the psychic chaos so that each content falls into place and the weltering confusion is held together by the protective circle.

The garden of Eden with its four rivers is such a symmetrical or circular figure divided into geometric patterns. As far as the individual is concerned, the order that the garden represents is important in the process of individuation. We all know that exposure to nature alleviates stress in humans. The garden of Eden represents this archetype: the paradisal condition of total harmony and totality, containing the symmetrical four rivers that encompass the whole 
world. The idea of the garden creates order within chaos ${ }^{11}$. As far as its societal function is concerned, the text of Gn 1-3 probably originated in a situation in which Israel or Judah was under all kinds of pressure. The longing back to the perfect state of the garden is meant to alleviate the contemporary confusion, stress, pressure or chaos. The exilic situation obviously comes to mind.

\subsection{The tree of life}

The tree of life, which we explicitly find in the garden of Eden (Gn 3:22) is as such not an archetype, but a symbol which in some cultures represents the mother archetype yearning for life and procreation (Jung 196:140; Von Franz 1978:163-166; cf also Cook 1974). Humanity's struggle to come to terms with death and its yearning for eternal life is also expressed through this symbol ${ }^{12}$. In the Genesis myth the fact that Adam and Eve are driven from the garden in view of preventing them from eating from the tree and obtaining eternal life, is an indication of the inner conflict within humans: it recognises the fact that humans are mortal, but also expresses their intense yearning for immortality. The latter can only be satisfied if life exists after death, but the conscious knowledge of what will be the case after death is withheld from humans (expressed in their not being allowed to eat from the tree of knowledge on a continuous basis).

\subsection{The serpent as shadow figure}

The serpent personifies the shadow archetype or the dark, 'negative', vulnerable dimensions of humanity. The shadow represents those things which humans naturally attempt to avoid, being regarded by them as suffering and therefore 'evil'. According to Jung (cf above) the shadow is not necessarily evil, since what constitutes 'evil' is always the result of a human judgement call. For Jung the shadow

11 One cannot but notice the bitter irony that the most probable geographical location of the original Eden is within present-day Iraq (afflicted by war during the writing of this article).

12 Jung had provoking thoughts on the question of life after death. Humans have no objective proof that there is a life after death, but according to Jung the symbols and myths of the collective unconscious may give some indication, in an analogous way that they often supply information about other matters of which humans are unconscious (e.g. the future). For an absorbing discussion on this topic, see Jung (1963:330-358). 
almost always plays a positive part in a persons's individuation process: it often represents the chaos from which creation emerges, the flower that grows on the dunghill. Even in the Genesis story the serpent is not outrightly presented as being evil. In Genesis 3:1 he explicitly features as a creature of God and the Hebrew term arum need not be interpreted as evil ( $r a$ in Hebrew) but rather as 'clever' or 'shrewd'. The snake (not Satan at this stage) actually wants to be transparent to the humans to whom God gave false information (e.g. that they will die). Jung emphasises that humans' fear of blasphemy should not blind them for the fact that it was after all the Creator who put the snake and the two trees in the garden. Taken to its logical consequence this implies that God was responsible for the fall and not his human creatures. This truth is indirectly communicated through the myth by the author. Deep down, perhaps without even realising it, the author of Genesis 3 accuses God for humankind's troubles. This is the start of the divine drama ${ }^{13}$ which is experienced by humanity and enacted in his psyche. How this develops further is indicated in the protevangelium of Genesis 3:15, but also in the rest of the Bible, especially the book of Job and the Gospels of the New Testament (cf Jung 1965; Scheffler 1991).

\subsection{The meaning of the story of the fall}

In terms of Jung's psychology the story of the fall is actually an account that explains the birth of human consciousness and knowledge. According to the serpent humans will not die after they have eaten the forbidden fruit, but will gain knowledge which will enable them to distinguish between good and evil (Gn 3:5). According to the myth they became aware that they were naked after they ate the fruit, suggesting or interpreting that nakedness may have something to do with evil. Consequently they were afraid of God,

13 That Jung interprets Gen 3:15 as protevangelium (1965:56-57) betrays on the one hand his traditional Christian background, as well as the fact that he did not pay much attention to the results of historical-critical exegesis (cf e.g. Westermann [1974:353-355] and Von Rad [1972:92-93]: on Gen 3:15). In favour of Jung's view can be mentioned that the 'Messianic' interpretation of Genesis 3:15 is not of Christian origin but reaches into late Judaism (cf e g Targum Neofiti). Viewed as expression of the 'divine drama' that occurs in the collective human soul, Jung's view comes close to the 'ethical' interpretation of Philo and Mar Isodad von Merw (850 C E) in which the enmity in Gen 3:15 refers to the continuous battle between humankind and the power of evil (cf Westermann 1974:355). 
knowing that he would not be pleased with their growing consciousness.

Being able to make judgements of what humans regard as good or evil actually constitutes the primordial start of the question of morality and ethics. The awakening into consciousness is not (as they initially expected) an euphoric enlightenment, but part and parcel of the human predicament. The myth expresses humanity's primordial experience of the world as suffering which is the result of $\sin$ (= their disobedience to God). However, what happened was not contra voluptatem deo - he willed it. The shadow (interpreted by humans as suffering, sin and evil) is essentially part of human nature. Ironically, it is only through obtaining knowledge (becoming conscious) that humans become aware of this and consequently suffer. Moreover, it is also through a process of individuation (gaining insight into and integrating one's dark side) that humans are assisted in their struggle.

Most people merely adhere to the laws and prescriptions that society in its various forms demands from them, one-dimensionally (cf Marcuse 1964) following the way of the least resistence as it were. Most people do not realise that the primordial struggle in humanity as expressed by the myth of Genesis 1-3 lies at the basis of all morality, ethics and the laws that give expression to it. As such it is significant that the Pentateuch, or 'law of Moses' should have this myth as its preamble. It is also essential that any (post)modern ethic that wants to draw on the Pentateuch for inspiration, should reflect on the conditio humanitas which gives rise to the need for such an ethic.

\section{CONCLUSION: IN SEARCH OF A PENTATEUCHAL ETHIC (IN AFRICA)}

What has been said thus far represents only preliminary remarks on Genesis 1-3 from a Jungian perspective. The intention was to demonstrate how Jung, in his interpretation of a text, enters into a dialogue with the issues that are at stake in a text - issues which historical-critical exegetes who are merely interested in the sources, tradition, genres, Sitz im Leben and redaction of a text often avoid. A Jungian investigation needs not deny the value of the historical critical questions of a text, but can add immense value to its interpretation by looking for and analysing the underlying aspects of our common humanity which caused the Biblical texts to be 
produced in the first place. It therefore takes the fact that the texts were authored by human beings with peculiar psychic structures very seriously.

From Jung traditional exegetes we can learn (or at least emphatically remind ourselves) that our engagement with the Bible need not only (perhaps because of fear for eisegesis) be confined to an exegesis, commentary or exposition of the Pentateuch or Biblical text. James Barr once said that Biblical commentaries often have a limiting effect. In them exegetes attempt to explain or establish the ultimate, 'canonical' or 'correct' meaning of the text to which all should succumb. In South Africa (and more specifically in the context of the Pro-Pent Seminar where this paper was originally delivered) we confront ourselves on a continuous basis with the question what the Pentateuch has to say to us in the contemporary world, in Europe and Africa. This question is legitimate, because a so-called phenomenological engagement with the text which thrives for scientific respectability, but in the process denies the constitution of the reading subject, actually denies the full reality of human existence.

It follows that in our search for a relevant 'Pentateuchal ethic', we can benefit from engaging in a dialogue with the issues raised in the Pentateuch ( $\mathrm{e} g$ on general human suffering, poverty, landlessness, land exploitation, economics, exclusive nationalism and enmity, slavery, etc - cf Dt 15). Such a dialogue implies that the interpreter interacts with the text as a free person: he or she may express what (s)he finds useful or relevant, but also indicate what one in all honesty cannot believe anymore. This may sound radical, but who today will subscribe to the command in Deuteronomy 14:614 to be the first to kill your own brother, son, daughter, wife or friend, should they entice you to adhere to another religion? Or who are the Christian creditors that release the debt of their neighbours after every seven years (Dt 15:20)?

Entering into a dialogue with the issues of the text and the unconscious factors that call these issues into existence means not to be victimised by a certain dogmatic view of the text ( $\mathrm{e}$ that the Bible is the literal 'Word of God' to which we should succumb under all circumstances). The concept 'Word of God' can still 
function as a metaphor ${ }^{14}$ (although perhaps an unfortunate and easily to be misunderstood one) for the Bible as a literary treasure of our tradition which provides us with nearly unlimited anthropological and psychological insight. This insight can be enhanced if issues are compared with non-Biblical (e g European ${ }^{15}$, African or Indian) cultures in the search for the archetypes which all people universally share. This should be done with due respect for the ancient context(s) in which the Biblical writings originated. For to expect the Bible to speak directly and anachronistically in a context that cannot be equated to that of pre-industrial ancient Israel means - contrary to our own volition - to the demolish the Jewish-Christian faith (cf Scheffler 2000:11-17).

Jung's unorthodox view of the Bible and his apparent disregard for the authority (in the traditional sense) of the text should not be misunderstood as a downgrading of the Bible. On the contrary: the exploration and gaining insight into the archetypes of the collective unconscious which are shared by all human cultures (irrespective of their remoteness from one another in time and space), may provide us with insights and empower us to attitudes which can have a liberating effect upon us. As such, it can also draw us (as individuals or communities) closer to (our experience of) the divine or God.

The ethical implications of such liberating insights for the individual and society are numerous. Insight of individuals into their own instincts, fears and desires (their own shadow), may reduce interpersonal conflict and contribute to a spontaneous lifestyle which

14 Despite his dialogical approach to the Bible, Jung continued to refer to the term 'Word of God', thereby giving recognition to the status which the Bible occupies in traditional Christianity.

15 European Christians should constantly be reminded that - despite a 2000 year heritage of Christianity - European culture should not be equated with Biblical culture. The more knowledge about the Bible and its life-world becomes available, the more it becomes apparent that the Bible as such is actually foreign to western culture. Ironically, African Christians often note the correspondence between African and Biblical (especially Old Testament) culture (for a short introduction see Burden 1983). 
does not require rules and regulations in order to be ethically sound. Said Jung ([1917] 1966:53) $)^{16}$

Logically the opposite of love is hate, and of Eros, Phobos (fear); but psychologically it is the will to power. Where love reigns there is no will to power; and where the will to power is paramount, love is lacking. The one is but the shadow of the other ...

Jung (1965:117-118) emphasised that a mature ethic or morality has nothing to do with laws or conventions, but emerges from a growing consciousness. In this regard he referred to the Codex Bezae logion of Luke 6:4: 'Man, if indeed thou knowest what thou doest, thou art blessed; but if thou knowest not, thou art cursed, and a transgressor of the law' (quoted in Jung 1965:117; for the Greek see Aland 1973:66).

This also has implications for humanity at large. Insight into the common archetypes of the collective unconscious of humanity may reduce international conflict and war. This will occur when politicians and institutions of collective political decision making become aware of their own blind spots and consequently do not act from an attitude of 'power above justice'. To argue that such insights and attitudes by definition do not befit politicians, is to argue consciously that certain sections of human life should remain unconscious.

Stated differently: If Tony Blair and George W Bush had profound insight into Jungian psychology and his approach to the Bible they would not have attacked Iraq, calling on their respective nations 'to pray for the troops'.

Is there any relevance for Jungian Biblical interpretation in Africa?

Jung visited East Africa in 1925 to probe his views on the collective consciousness and archetypes (Wehr 1987:233-24; Jung 1963:282304). He was also much pleased with information on African thought supplied to him by the South African born author and student of the San people, Laurens van der Post (1976:154). But Van

16 With thankful recognition to Lida van Zyl, an appreciated friend and psychologist from Bloemfontein, who draw my attention to this statement by Jung. 
der Post also remarks: 'I thought that if there was anything at all which I knew and could understand, it was Africa and its people. But when we talked about Africa, I had to realize that Jung knew the archaic pattern of African life even better than I did, and revered it if possible even more deeply. There were a few moments when I felt a little disconcerted that a Swiss - and so of course he still was seemed to understand the deepest nature of my native continent better than I' (quoted in Wehr 1987:241).

Player (1997) gives a moving account on how he as a game warden had a remarkable friendship (despite a language barrier) with his black co-worker Magqubu Ntombela. He remarks: 'My time in Zululand with Magqubu had brought a slow but dramatic change to my attitude and feeling for landscape and to my relationship with the black people of my native land. He helped me to begin to overcome a darkness inside me. I was unaware of the psychological term at that time, but he helped me to deal with my shadow' (1997:8). In his commendation of Player's book former South African president Nelson Mandela comments: 'Their relationship and their commitment not only to each other but also to the conservation of wilderness is a shining example of the spirit of the people of this country'.

Ten years of democracy in South Africa has taught us that miracles and instant healings remains unlikely to occur. But the more black and whites gain insight into their different but also common thought patterns ${ }^{17}$, the more the chances of 'letting love reign' and surviving together are enhanced.

\section{Consulted literature}

Adler, G 1976 (ed). C G Jung: Letters: 2:1951-1961. London: Routledge \& Kegan Paul.

Aland, K $1973^{8}$. Synopsis quattuor evangeliorum. Stuttgart: Württembergische Bibelanstalt.

Brome, V 1978. Jung. London: Macmillan London.

Brown, S 1995: The myth of Sophia, in Miller (ed) 1995, 92-101.

17 The intention behind the often misunderstood book by Van Niekerk (1992; 1993; cf also 1996). Cf in this regard also the book by Sundermeier (1990), former missionary to South Africa and later Professor of History of Religions and Missiology at the University of Heidelberg, Germany. 
Bryant, C B 1983. Jung and the Christian way. London: Darton, Longman and Todd.

Burden, J J 1983. Are Shem and Ham blood brothers? OTE 1, 49-72.

Cook, R 1974. The tree of life: Image for the cosmos. New York: Avon Books.

Drewermann, E 1984. Tiefenpsychologie und Exegese: Band I: Die Wahrheit der Formen: Traum, Mythos, Märchen, Sage und Legende. Olten: Walter.

-, 1985. Tiefenpsychologie und Exegese: Band II: Die Wahrheit der Werke und der Worte: Wunder, Vision, Weissagung, Apokalypse, Geschichte, Gleichnis. Olten: Walter.

Earle, W J 1967. s v 'James, William', The Encyclopedia of Philosophy. New York: Macmillan Publishing Co.

Edinger, E 1986. The Bible and the psyche: Individuation symbolism in the Old Testament. Toronto: Inner City Books.

-, 1987. The Christian archetype: A Jungian commentary on the life of Christ. Toronto: Inner City Books.

Forryan, B \& Glover, J (compl) 1979. General index to the Collected Works of C G Jung. London: Routledge \& Keegan Paul.

Freud, S 1975. Der Mann Moses und die monotheistische Religion: Schriften über die Religion. Frankfurt am Main: Fischer Verlag.

-, 1979. Massenpsychologie und Ich-Analyse. Die Zukunft einer Illusion. Frankfurt am Main: Fischer Verlag.

-, 1980. Totem und Tabu. Frankfurt am Main: Fischer Verlag.

Gous, I 1992. Psychological survival strategies in Lamentations 3 in the light of neuro-linguistic programming, in Wessels, W \& Scheffler, E (eds), Old Testament science and reality: A mosaic for Deist. Pretoria: Verba Vitae, 317-341.

Hopcke, R H 1989. A guided tour of the Collected Works of C G Jung. Boston: Shambhala.

Harsch H 1972. Psychologische Interpretation biblischer Texte?, in Spiegel 1972, 49-59.

Jacobi, J 1968 ${ }^{7}$. The psychology of $C$ G Jung: An introduction with illustrations. London: Routledge \& Kegan Paul.

-, 1978. Symbols in an individual analysis, in Jung (ed) 1978, 323-374.

James, W 1902. The varieties of religious experience: A study in human nature. New York: Longmans, Green, and Co.

Jung, C G [1916]1966. The relations between the ego and the unconscious, in $C W 7,121-241$. London: Routledge \& Kegan Paul.

-, [1917] 1966. On the psychology of the unconscious, in $C W 7,1-119$. London: Routledge \& Kegan Paul.

-, [1925] 1977. Marriage as a psychological relationship, in CW 17, 189-201. London: Routledge \& Kegan Paul. 
-, [1926] 1969. Spirit and life, in $C W$ 8, 325-326. London: Routledge \& Kegan Paul.

-, [1927] 1970. Women in Europe, in $C W 10,113-133$. London: Routledge \& Kegan Paul.

-, [1938] 1969. Psychology and religion: East and west. London: Routledge \& Kegan Paul. (CW 11.)

-, [1939] 1968. Conscious, unconscious and individuation, in $C W$ 9(1), 275289. London: Routledge \& Kegan Paul.

-, [1946] 1966. The psychology of the transference, in $C W 16,163-323$. London: Routledge\& Kegan Paul.

-, [1948] 1969. Instinct and the unconscious, in $C W$ 8, 129-138. London: Routledge \& Kegan Paul.

-, [1950] 1968. Concerning rebirth, in $C W$ 9(1), 113-147. London: Routledge \& Kegan Paul.

-, 1952. Antwort auf Hiob. Zürich: Rascher Verlag.

-, [1954] 1968. Archetypes of the collective unconscious, in $C W$ 9(1), 31-42. London: Routledge \& Kegan Paul.

-, [1958] 1970. Flying saucers: A modern myth of things seen in the skies, in CW 10, 307-433. London: Routledge \& Kegan Paul.

-, [1959] 1968. Aion: Researches into the phenomenology of the self. London: Routledge \& Kegan Paul. (CW 9[2].)

-, 1963. Memories, dreams, reflections. Glasgow: Collins.

-, 1965. Answer to Job. London: Hodder \& Stoughton.

-, 1975. The vision seminars. Zürich: Spring Publications.

-, (ed) 1978. Man and his symbols. London: Pan Books.

Kille, D A 1995. Jacob - A study in individuation, in Miller (ed) 1995, 40-54.

-, 2001. Psychological Biblical criticism. Minneapolis: Fortress Press.

Leiner, M 1993. Grundfragen einer Textpsychologischen Exegese des Neuen Testaments. Doctoral dissertation, University of Heidelberg, Germany.

Maddi, S R 197633. Personality theories: A comparative analysis. Homewood: The Dorsey Press.

Marcuse, H 1964. One dimensional man: Studies in the ideology of advanced industrial society. London: Routledge \& Kegan Paul.

McGuire, W \& Hull, R F C (eds) 1980. C G Jung speaking: Interviews and encounters. London: Pan Books.

Miller, D L (ed) 1995. Jung and the interpretation of the Bible. New York: Continuum.

Newheart, M W 1995. Johannine Symbolism, in Miller (ed) 1995, 71-91.

Player, I 1997. Zululand wilderness: Shadow and soul. Cape Town: David Philip Publishers. 
Rollins, W G 1983. Jung and the Bible. Atlanta: John Knox Press.

-, 1995. Psychology, Hermeneutics, and the Bible, Miller (ed) 1995:9-39.

Rychlak, J F 1973. Introduction to personality and psychotherapy: A theoryconstruction approach. Boston: Houghton Mifflin Company.

Scharfenberg, J 1971. Sigmund Freud und seine Religionskritik als Herausforderung für den Christlichen Glauben. Göttingen: Vandenhoeck \& Ruprecht.

Scheffler, E H 1988. A psychological reading of Luke 12:35-48. Neotestamentica 22, 355-371.

-, 1990. The game Samuel played: A psychological interpretation of the relationship between Samuel and Saul. OTE 3, 263-273.

-, 1991. Jung's Answer to Job: An appraisal. OTE 4, 327-341.

-, 1992. Qohelet's positive advice. OTE 6, 248-271.

-, 1994. The psychological approach to the (Hebrew) Bible. OTE 7(4), 148159.

-, 2000. Reading the Bible in context, in Boshoff, W S, Scheffler, E H \& Spangenberg, I J J, Ancient Israelite literature in context, 11-17. Pretoria: Protea Book House.

Smit, D J 1988. Responsible hermeneutics: A systematic theologian's response to the readings and readers of Luke 12:35-48. Neotestamentica 22, 441-484.

Spiegel, Y (Hrsg) 1972. Psychoanalitische Interpretationen biblischer Texte. München: Kaiser Verlag.

Steyn, J 1984. Some psycholinguistic factors involved in the discourse analysis of ancient texts. Theologia Evangelica 172, 51-65.

-, 1985. Christusverhaal en lewensin. Theologia Evangelica. 18, 6-18.

Strecker, G \& Schnelle, U 1983. Einführung in die neutestamentliche Exegese. Göttingen: Vandenhoeck \& Ruprecht.

Sundermeier, T 1990. Nur gemeinsam können wir leben: das Menschenbild schwarzafrika-nischer Religionen. Gütersloh: Gerd Mohn.

Theissen, G 1983. Psychologische Aspekte paulinischer Theologie. Göttingen: Vandenhoeck \& Ruprecht.

Uleyn, A 1985. Psychoanalytisch lezen in de Bijbel. Hilversum: Gooi en Sticht.

Van den Berg, J H 1958. Psychologie en geloof: Een kroniek en een standpunt. Nijkerk: Callenbach.

Van der Post, L 1976. Jung and the story of our time. Middlesex: Penguin.

Van Heerden, W 2003. Psychological interpretations of the book of Jonah. OTE 16(3), 718-713.

Van Niekerk, A S 1992. Sáám in Afrika. Kaapstad: Tafelberg.

-, 1993. One destiny. Cape Town: Tafelberg.

-, 1996. Anderkant die reënboog. Kaapstad: Tafelberg. 
Von Franz, M-L 1978. The process of individuation, in Jung (ed) 1978:157254.

Von Rad, G ${ }^{2}$ 1972. Genesis: A commentary. London: SCM (OTL).

Watt, T 1995. Joseph's dreams, in Miller (ed) 1995:55-70.

Wehr, G 1987. Jung: A biography. London: Shambhala.

Westermann, C 1974. Genesis: I. Teilband: Genesis 1-11. Neukirchen: Neukirchener Verlag. 